УДК 544.35.038.1 + 544.353.2

\title{
DENSITY AND SOLVATION EFFECTS OF IMIDAZOLIUM BASED IONIC LIQUIDS IN PROPYLENE CARBONATE
}

\author{
A.V. Riabchunova *,a , V.M. Karabtsova *,b, O.N. Kalugin *,c \\ * V.N.Karazin Kharkiv National University, School of chemistry, Department of Inorganic Chemis- \\ try, Svobody sq.,4, Kharkiv, 61022, Ukraine
}

a. e-mail: ryabchunova.anastasia@gmail.com, ORCHID: 0000-0001-9373-799X

b. e-mail: karabtsovav@gmail.com, ORCHID: 0000-0001-9292-6190

c. e-mail: onkalugin@gmail.com, ORCHID: 0000-0003-3273-9259

The results of densimetry investigation of the solutions of 1-butyl-3-methylimidazolium tetrafluoroborate $\left(\mathrm{BMIMBF}_{4}\right)$, hexafluorophosphate $\left(\mathrm{BMIMPF}_{6}\right)$ and bromide $(\mathrm{BMIMBr})$ in propylene carbonate $(\mathrm{PC})$ at 298.15, $318.15,338.15$ and $358.15 \mathrm{~K}$ are presented and discussed in terms of apparent partial molar volumes and solvation contribution. Density measurements were carried out using the vibrational tube densitometer Mettler Toledo DM 50 with accuracy $\pm 3 \cdot 10^{-5} \mathrm{~g} / \mathrm{cm}^{3}$.

The limiting partial molar volumes of investigated ionic liquids in PC were obtained from density experiment using Masson equation and divided into ionic contributions. Limiting partial molar volumes of $\mathrm{BMIMBF}_{4}, \mathrm{BMIMPF}_{6}$ and $\mathrm{BMIMBr}$ in $\mathrm{PC}$ slightly increase with the increase of temperature. The limiting partial molar volumes of $\mathrm{BMIM}^{+}$cation obtained from three ionic liquids with different anions was found to have the same value, $115 \mathrm{~cm}^{3} / \mathrm{mol}$ at $298.15 \mathrm{~K}$.

The intrinsic volume of $\mathrm{BMIM}^{+}$cation estimated from quantum chemical calculations at the M062X/6-311++G(d,p) theory level exceeds one obtained from density experiment indicating that solvation of cation has a negative contribution to the volume of ion in propylene carbonate.

In order to investigate the microscopic structure of the $\mathrm{BMIM}^{+}$solvation shell in $\mathrm{PC}$, molecular dynamics simulation of the infinitely dilute solution was carried out in the NVT ensemble at $298.15 \mathrm{~K}$. The results of the simulation reveal that 5-6 PC molecules forming the first solvation shell penetrate into the inner space of the cation, which agrees with the results of a density experiment treatment. From the analysis of the cationsolvent site-site radial distribution functions and the running coordination numbers it was established that the most probable coordination center of PC molecule is carbonyl oxygen.

Keywords: densimetry, density, apparent partial molar volume, solvation, 1-butyl-3-methylimidazolium, tetrafluoroborate, hexafluorophosphate, bromide, propylene carbonate, molecular dynamics simulation.

\section{Introduction}

The room temperature ionic liquids (RTILs) due to their ionic structure and liquid state at room temperature have a plenty of specific features such as negligible vapor pressure, non-flammability, broad range of liquid state, high thermal stability, high solvating capacity and wide electrochemical window [1]. As a result, RTILs have a variety of different application areas [2] such as bio-catalysis and organic reactions [3], lubricants [4], separation and extraction [5], energy storage and chemical power sources [6]. Mixtures of RTILs (especially imidazolium based RTILs) with aprotic solvents like propylene carbonate are widely used in lithium-ion batteries [7], super capacitors [8] and solar cells [9] due to lower viscosity and higher ion mobility.

Taking into account growing interest for electrochemical application deeper understanding of physicochemical properties of the RTILs mixture with molecular solvents is needed since this information is vital for optimization and development of new electrochemical devices. The most important properties for electrochemical application of RTILs mixtures are mainly defined by microscopic structure and ion-ion and ion-solvent interactions. To date, there have been made several attempts to study such interactions using theoretical and experimental approaches, including scanning electron microscopy (SEM) [10], quantum chemical calculation [11], thermodynamic and transport properties [12-15], NMR spectroscopy [16], IR spectroscopy, Raman spectroscopy [17-18]. But the role of cation solvation by solvent molecules is still remains unclear. It seems appropriate to use a combination of experimental and computing methods for examination of solvation structure in such complicated systems like mixtures of RTILs with aprotic solvents. 
Densimetry is one of the simplest, fast and informative experimental methods which can give the information about solvation effects by means of apparent partial molar volumes of electrolytes and ions. In spite of the fact that literature data on density of some RTILs in PC [19-22] is available, information about the apparent partial molar volumes of RTILs in such systems is scarce.

Based on this, in current work density of binary mixtures of three RTILs 1-butyl-3methylimidazolium tetrafluoroborate $\left(\mathrm{BMIMBF}_{4}\right)$, hexafluorophosphate $\left(\mathrm{BMIMPF}_{6}\right)$ and bromide (BMIMBr) with propylene carbonate (PC) was measured with high accuracy in the temperature range $298.15-358.15 \mathrm{~K}$. The apparent partial molar volumes $\left(V_{\phi}\right)$ of the mixtures were calculated and fitted by the Masson equation [23] to discuss the concentration dependence of $V_{\phi}$ and to find limiting partial molar volumes $\bar{V}_{2}^{0}$ in order to evaluate the solvation effects. Additionally, the microscopic structure of the first solvation shell of 1-butyl-3-methylimidazolium in propylene carbonate at infinite dilution was studied by means of molecular dynamics simulation.

\section{Experimental section}

Materials. Ionic liquids 1-butyl-3-methylimidazolium tetrafluoroborate and bromide were purchased from Merck and 1-butyl-3-methylimidazolium hexafluorophosphate was purchased from Solvionic (mass fraction purity 99.0 - 99.5\%). RTILs were preliminary dried under reduced pressure in ultrasonic bath at $50-60{ }^{\circ} \mathrm{C}$ for 4-5 hours. 1-Butyl-3-methylimidazolium bromide was dried under reduced pressure in water bath at $85^{\circ} \mathrm{C}$ for $4-5$ hours using rotary evaporator and then recrystallized using liquid nitrogen. Propylene carbonate (Merck 99\%) was distilled under reduced pressure and stored over $4 \AA$ molecular sieves, and redistilled under reduced pressure prior to use. The water content in propylene carbonate was less than $80 \mathrm{ppm}$ as was controlled by Karl Fischer titration.

Measurements. A set of 10 solutions for each RTIL+PC systems in the range of concentrations from $5 \cdot 10^{-3}$ to $1 \cdot 10^{-1} \mathrm{~mol} / \mathrm{dm}^{3}$ were used for the density measurements. Solutions were prepared from concentrated one gravimetrically by dilution taking into account the correction on Archimedean force. All the solutions were handled in a dried glovebox over $\mathrm{P}_{2} \mathrm{O}_{5}$ and tested for a water content that was about 100 ppm for each solution.

Density measurements were carried out using the vibrational tube densitometer Mettler Toledo DM 50 at $298.15,318.15,338.15$ and $358.15 \mathrm{~K}$ with accuracy $0.02 \mathrm{~K}$ (Peltier temperature control) and viscosity correction. Each value of solution density is an average from at list five measurements with repeatability $\pm 2 \cdot 10^{-5}$ while the instrument accuracy is reported to be $\pm 3 \cdot 10^{-5} \mathrm{~g} / \mathrm{cm}^{3}$. The calibration of densitometer was made using ultra-pure water and air at atmospheric pressure and $293.15 \mathrm{~K}$.

\section{Results and discussion}

Density and partial molar volumes

The experimental density data for studied systems are presented in Table 1. Literature data on the density of propylene carbonate at $298.15 \mathrm{~K}$ is in the range of $1.1890-1.2001 \mathrm{~g} / \mathrm{cm}^{3}$ [24-35].

The apparent partial molar volumes $\left(V_{\phi}\right)$ of RTILs in PC were calculated from experimental densities of solvent $\left(d_{0}\right)$ and solutions $(d)$, respectively:

$$
V_{\phi}=\left(1-\frac{d}{d_{0}}\right) \frac{1000}{c}+\frac{M_{2}}{d_{0}},
$$

where $M_{2}$ is a molar mass of RTIL.

Obtained data (Fig. 1) were fitted by Masson equation (eq. 2) where apparent partial molar volume of electrolyte has a linear dependence versus square root from molar concentration [23].

$$
V_{\phi}=\bar{V}_{2}^{0}+S_{V} \cdot c^{1 / 2}
$$

The values of limiting partial molar volumes $\bar{V}_{2}^{0}$ were obtained by extrapolation of the concentration dependence to the infinite dilution. As can be observed from Fig. 2 limiting partial molar volumes of studied RTILs in PC slightly increase with the increase of temperature. 
Table 1. Density change of $\mathrm{BMIMBF}_{4}, \mathrm{BMIMPF}_{6}, \mathrm{BMIMBr}$ solutions in $\mathrm{PC}$ compared to the pure solvent $\left(\Delta d, \mathrm{~g} / \mathrm{cm}^{3}\right)$ as a function of molar concentrations $\left(c, \mathrm{~mol} / \mathrm{dm}^{3}\right)$ at studied temperatures

\begin{tabular}{|c|c|c|c|c|c|}
\hline$c$ & $\Delta d$ & $c$ & $\Delta d$ & $c$ & $\Delta d$ \\
\hline \multicolumn{2}{|c|}{$\mathrm{BMIMBF}_{4}$} & \multicolumn{2}{|c|}{$\mathrm{BMIMPF}_{6}$} & \multicolumn{2}{|c|}{ BMIMBr } \\
\hline \multicolumn{6}{|c|}{$T=298.15 \mathrm{~K}, d_{0}=1.19932$} \\
\hline 0.00663 & 0.00012 & 0.00641 & 0.00033 & 0.00497 & 0.00038 \\
\hline 0.01120 & 0.00029 & 0.01050 & 0.00050 & 0.00962 & 0.00045 \\
\hline 0.01850 & 0.00042 & 0.01690 & 0.00081 & 0.01520 & 0.00063 \\
\hline 0.02850 & 0.00051 & 0.02510 & 0.00117 & 0.02230 & 0.00079 \\
\hline 0.03700 & 0.00045 & 0.03400 & 0.00142 & 0.03180 & 0.00109 \\
\hline 0.04420 & 0.00061 & 0.04430 & 0.00262 & 0.04290 & 0.00125 \\
\hline 0.05600 & 0.00070 & 0.05660 & 0.00265 & 0.05480 & 0.00165 \\
\hline 0.07930 & 0.00059 & 0.07370 & 0.00244 & 0.06760 & 0.00176 \\
\hline 0.08400 & 0.00081 & 0.08560 & 0.00333 & 0.08310 & 0.00219 \\
\hline 0.12200 & 0.00074 & 0.12420 & 0.00281 & 0.11980 & 0.00299 \\
\hline \multicolumn{6}{|c|}{$T=318.15 \mathrm{~K}, d_{0}=1.17814$} \\
\hline 0.00651 & 0.00030 & 0.00630 & 0.00033 & 0.00489 & 0.00032 \\
\hline 0.01100 & 0.00050 & 0.01030 & 0.00048 & 0.00945 & 0.00046 \\
\hline 0.01820 & 0.00051 & 0.01660 & 0.00085 & 0.01490 & 0.00067 \\
\hline 0.02800 & 0.00065 & 0.02470 & 0.00116 & 0.02190 & 0.00094 \\
\hline 0.03640 & 0.00073 & 0.03340 & 0.00145 & 0.03120 & 0.00115 \\
\hline 0.04340 & 0.00075 & 0.04350 & 0.00283 & 0.04220 & 0.00148 \\
\hline 0.05500 & 0.00088 & 0.05560 & 0.00270 & 0.05380 & 0.00174 \\
\hline 0.07790 & 0.00079 & 0.07240 & 0.00248 & 0.06640 & 0.00206 \\
\hline 0.08260 & 0.00110 & 0.08410 & 0.00340 & 0.08170 & 0.00249 \\
\hline 0.11990 & 0.00109 & 0.12210 & 0.00314 & 0.11770 & 0.00328 \\
\hline \multicolumn{6}{|c|}{$T=338.15 \mathrm{~K}, d_{0}=1.15702$} \\
\hline 0.00640 & 0.00029 & 0.00618 & 0.00033 & 0.00480 & 0.00032 \\
\hline 0.01080 & 0.00041 & 0.01010 & 0.00046 & 0.00928 & 0.00047 \\
\hline 0.01790 & 0.00048 & 0.01630 & 0.00078 & 0.01460 & 0.00065 \\
\hline 0.02750 & 0.00062 & 0.02420 & 0.00107 & 0.02150 & 0.00090 \\
\hline 0.03570 & 0.00071 & 0.03280 & 0.00149 & 0.03070 & 0.00113 \\
\hline 0.04260 & 0.00069 & 0.04280 & 0.00283 & 0.04140 & 0.00147 \\
\hline 0.05400 & 0.00090 & 0.05460 & 0.00274 & 0.05290 & 0.00182 \\
\hline 0.07650 & 0.00087 & 0.07110 & 0.00251 & 0.06520 & 0.00209 \\
\hline 0.08110 & 0.00107 & 0.08260 & 0.00346 & 0.08020 & 0.00258 \\
\hline 0.11780 & 0.00122 & 0.11990 & 0.00319 & 0.11560 & 0.00344 \\
\hline \multicolumn{6}{|c|}{$T=358.15 \mathrm{~K}, d_{0}=1.13587$} \\
\hline 0.00628 & 0.00020 & 0.00607 & 0.00030 & 0.00471 & 0.00030 \\
\hline 0.01060 & 0.00031 & 0.00992 & 0.00047 & 0.00911 & 0.00045 \\
\hline 0.01750 & 0.00041 & 0.01600 & 0.00076 & 0.01440 & 0.00066 \\
\hline 0.02700 & 0.00056 & 0.02380 & 0.00114 & 0.02120 & 0.00088 \\
\hline 0.03510 & 0.00067 & 0.03220 & 0.00152 & 0.03010 & 0.00116 \\
\hline 0.04190 & 0.00075 & 0.04200 & 0.00288 & 0.04060 & 0.00152 \\
\hline 0.05310 & 0.00093 & 0.05360 & 0.00281 & 0.05190 & 0.00188 \\
\hline 0.07520 & 0.00092 & 0.06980 & 0.00256 & 0.06410 & 0.00217 \\
\hline 0.07960 & 0.00125 & 0.08110 & 0.00356 & 0.07870 & 0.00269 \\
\hline 0.11560 & 0.00136 & 0.11770 & 0.00326 & 0.11350 & 0.00364 \\
\hline
\end{tabular}

In order to estimate the ionic contribution into limiting partial molar volumes we used schemes (3-5) and available literature data for anions and lithium salts [36] in PC at $298.15 \mathrm{~K}$.

$$
\begin{aligned}
& \mathrm{Br}^{-} \stackrel{\mathrm{LiBr}}{\longrightarrow} \mathrm{Li}^{+} \stackrel{\mathrm{LiBF}_{4}}{\longrightarrow} \mathrm{BF}_{4}^{-} \stackrel{\mathrm{BMIMBF}_{4}}{\longrightarrow} \mathrm{BMIM}^{+} \\
& \mathrm{Br}^{-} \stackrel{\mathrm{LiBr}}{\longrightarrow} \mathrm{Li}^{+} \stackrel{\mathrm{LiPF}_{6}}{\longrightarrow} \mathrm{PF}_{6}^{-} \stackrel{\mathrm{BMIMPF}_{6}}{\longrightarrow} \mathrm{BMIM}^{+}
\end{aligned}
$$




$$
\mathrm{Br}^{-} \stackrel{\text { BMIMBr }}{\longrightarrow} \mathrm{BMIM}^{+}
$$

The values of $\mathrm{BMIM}^{+}$cation limiting partial molar volume $\bar{V}_{i}^{0}$ and initial literature data are listed in Table 2.

The results listed in Table 2 demonstrate that the values of $\mathrm{BMIM}^{+}$cation limiting partial molar volume obtained from three RTILs with different anions are close to each other that confirms reliability of our experimental data and the used dividing schemes.

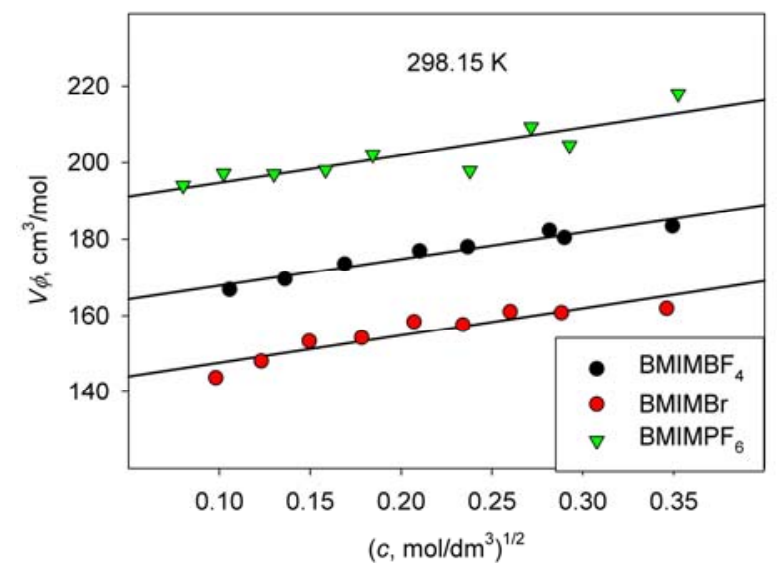

Figure 1. Concentration dependence of apparent partial molar volume of RTILs in PC at $298.15 \mathrm{~K}$. The same tendency is observed at other temperatures.

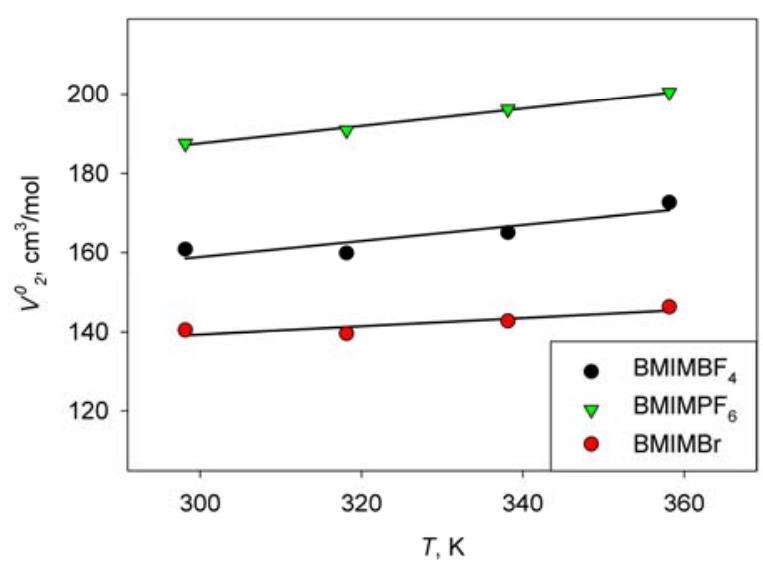

Figure 2. Temperature dependence of limiting partial molar volumes of RTILs in PC.

Table 2. Limiting partial molar volumes of electrolytes and ions at $298.15 \mathrm{~K}$. The corresponding values for anions are taken form ref. [36].

\begin{tabular}{ccc}
\hline $\bar{V}_{2}^{0}, \mathrm{~cm}^{3} / \mathrm{mol}$ & $\bar{V}_{-}^{0}, \mathrm{~cm}^{3} / \mathrm{mol}[36]$ & $\bar{V}_{+}^{0}, \mathrm{~cm}^{3} / \mathrm{mol}$ \\
\hline $\mathrm{BMIMBF}_{4}$ & $\mathrm{BF}_{4}^{-}$ & $\mathrm{BMIM}^{+}$ \\
161 & 47 & 114 \\
$\mathrm{BMIMPF}_{6}$ & $\mathrm{PF}_{6}^{-}$ & $\mathrm{BMIM}^{+}$ \\
188 & 73 & 115 \\
$\mathrm{BMIMBr}_{141}$ & $\mathrm{Br}^{-}$ & $\mathrm{BMIM}^{+}$ \\
\hline
\end{tabular}

For more detailed interpretation of obtained data it was assumed that limiting partial molar volume of ion can be represented by the sum of intrinsic ionic volume $\bar{V}_{\text {intr }}^{0}$ and the additional value $\Delta \bar{V}_{i}^{0}$ that describes the solvation effects in the nearest space around the ion:

$$
\bar{V}_{i}^{0}=\bar{V}_{i n t r}^{0}+\Delta \bar{V}_{i}^{0}
$$

To estimate the intrinsic molar volume of $\mathrm{BMIM}^{+}$cation first quantum chemical calculation at the M062X/6-311++G(d, p) theory level was carried out in order to optimize its geometry in vacuum using Gaussian 09 [37] program package. Then the cation volume that defined as one inside a contour of 0.001 electron/Bohr ${ }^{3}$ density was estimated by averaging ten corresponding values. The ion radius was calculated from an assumption of ion sphericity and was found to be $0.364 \mathrm{~nm}$. Finally the average intrinsic molar volume of $\mathrm{BMIM}^{+} \bar{V}_{\text {intr }}^{0}$ was estimated as $122 \mathrm{~cm}^{3} / \mathrm{mol}$. Comparison of the intrinsic $\left(122 \mathrm{~cm}^{3} / \mathrm{mol}\right)$ and experimental limiting partial molar volumes $\left(115 \mathrm{~cm}^{3} / \mathrm{mol}\right)$ allows one to make a conclusion about the "negative" contribution of solvation $\left(\Delta \bar{V}_{i}^{0}=-7 \mathrm{~cm}^{3} / \mathrm{mol}\right)$ to the value of $\bar{V}_{+}^{0}$ for $\mathrm{BMIM}^{+}$in PC implying penetration of inner space of cation by solvent molecules. 
Molecular dynamics simulation

In order to investigate the microstructure of the $\mathrm{BMIM}^{+}$(Fig. 3) solvation shell in PC, a molecular dynamics (MD) simulation of the system of an infinitely dilute solution was carried out.

The MD simulation was performed by using MDNAES simulation package [38]. The interparticle interactions were represented by a sum of Coulomb and Lennard-Jones (LJ) $(12,6)$ potentials.

$$
U(\mathrm{r})=4 \varepsilon\left[\left(\frac{\sigma}{r}\right)^{12}-\left(\frac{\sigma}{r}\right)^{6}\right]
$$

The cross-terms of LJ $(12,6)$ were calculated via Lorenz-Berthelot combining rules:

$$
\varepsilon_{i j}=\sqrt{\varepsilon_{i i} \varepsilon_{j j}}, \quad \sigma_{i j}=\left(\sigma_{i i}+\sigma_{j j}\right) / 2
$$

Electrostatic interactions were treated by using the reaction field method:

$$
U_{i j}^{R F}=\frac{z_{i} z_{j} e^{2}}{4 \pi \varepsilon_{0}}\left(\frac{1}{r_{i j}}-b_{0} \frac{r_{i j}}{2 R_{\text {cut }}^{3}}+\frac{1}{R_{\text {cut }}}\left(\frac{b_{0}}{2}-1\right)\right), \quad b_{0}=\frac{2\left(\varepsilon_{R F}-1\right)}{2 \varepsilon_{R F}+1},
$$

where $R_{\text {cut }}$ and $\varepsilon_{\mathrm{RF}}$ are cut off radius and dielectric constant above the $R_{\text {cut }}$ radius, respectively. The technique of the shifted force was applied to $\operatorname{LJ}(12,6)$ interactions.

A simulation of a system that consists of $215 \mathrm{PC}$ molecules and $1 \mathrm{BMIM}^{+}$in cubic cell with periodic boundary conditions in all directions was treated in the $N V T$ ensemble at $298.15 \mathrm{~K}$ by using the Berendsen thermostat. The time step was set equal to $0.5 \mathrm{fs}$. The investigated system was undergone the equilibration for $500 \mathrm{ps}$ followed by calculation of the structural parameters for another $500 \mathrm{ps}$. The dielectric constant and density of system were set $64.92 \mathrm{~kg} / \mathrm{m}^{3}$ [39] and $1198.0 \mathrm{~kg} / \mathrm{m}^{3}$ [40] respectively (equal to the parameters of the pure solvent).

In the current work for propylene carbonate the parameters of the force field model were taken from [41]. The PC model had seven centers with united atoms: $\mathrm{CH}, \mathrm{CH}_{2}$ and $\mathrm{CH}_{3}$, which were replaced by single interaction centers (Fig. 4).

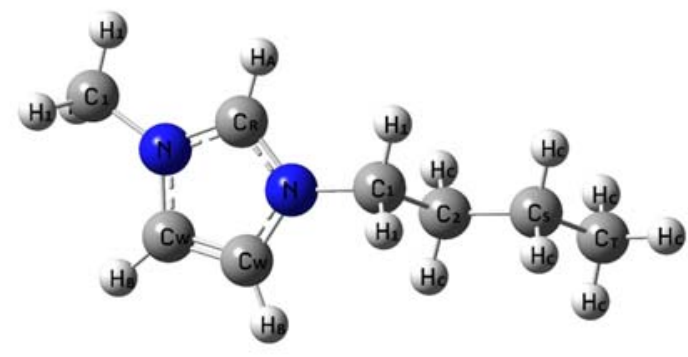

Figure 3. Structure of 1-butyl-3-methylimidazolium cation with atom designation used in the MD simulation.

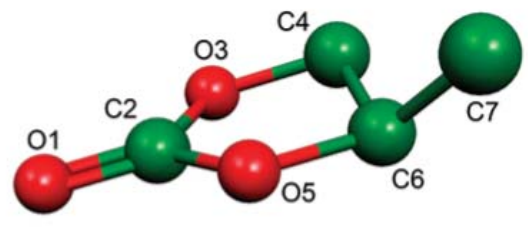

Figure 4. Structure of united atom model of the PC molecule.

Table 4. The partial charges on the $\mathrm{BMIM}^{+}$atoms $(q,|\mathrm{e}|)$ according to the Mondal and Balasubramanian model [42] (original) and used in the present work

\begin{tabular}{ccc}
\hline Site & Original & Present work \\
\hline $\mathrm{N}$ & 0.140 & 0.184 \\
$\mathrm{C}_{\mathrm{R}}$ & -0.010 & -0.013 \\
$\mathrm{C}_{\mathrm{W}}$ & -0.110 & -0.144 \\
$\mathrm{H}_{\mathrm{A}}$ & 0.180 & 0.236 \\
$\mathrm{H}_{\mathrm{B}}$ & 0.170 & 0.223 \\
$\mathrm{C}_{1}$ & -0.250 & -0.328 \\
$\mathrm{H}_{1}$ & 0.120 & 0.1574 \\
$\mathrm{C}_{2}$ & -0.076 & -0.076 \\
$\mathrm{H}_{\mathrm{C}}$ & 0.098 & 0.098 \\
$\mathrm{C}_{\mathrm{S}}$ & -0.196 & -0.196 \\
$\mathrm{C}_{\mathrm{T}}$ & -0.294 & -0.294 \\
Total cation charge & +0.79 & +1.0 \\
\hline
\end{tabular}


Non-rigid and all-atom BMIM $^{+}$force field of Mondal and Balasubramanian [42] with the modification of partial charges proposed recently [43] was used for the present MD simulation. Particularly, the partial charges on the $\mathrm{BMIM}^{+}$atoms were modified to restore the total charge of cation equal +1 in the infinitely dilute solution as compare with one equal to +0.79 in the original model of Mondal and Balasubramanian (Table 4).

The microscopic structure of the $\mathrm{BMIM}^{+}$cation solvation shell in $\mathrm{PC}$ was analyzed in terms of the radial distribution function (RDF) and the running coordination numbers (RCN). From the analysis of cation-solvent site-site RDFs and RCNs one can conclude that the most probable coordination center of PC molecule is carbonyl oxygen. It interacts mostly with atoms of imidazole ring of the $\mathrm{BMIM}^{+}$cation.

As can be seen from the Fig. 5 carbonyl oxygen atom of $\mathrm{PC}(\mathrm{O} 1)$ are mostly coordinated by the $\mathrm{H}_{\mathrm{A}}$ atom bearing the highest positive charge within imidazole ring of the $\mathrm{BMIM}^{+}$cation (Table 4). $\mathrm{O} 1$ are less coordinated by the $\mathrm{H}_{\mathrm{B}}$ atoms and even less by carbon atoms of imidazole ring $\mathrm{C}_{\mathrm{R}}$ and $\mathrm{C}_{\mathrm{W}}$.

Based on interatomic RDF the limits of the first solvation shell were evaluated. This gave the opportunity for estimation of RCN (Fig. 6). The first maxima on the RDF corresponds to the most probable distances between two neighboring atoms $\left(r_{\max , 1}\right)$ and the first minima corresponds to the first solvation shell radii $\left(r_{\min , 1}\right)$ (Table 5). Coordination numbers (Table 5 ) were obtained from RCN function by using first solvation shell radii acquired from RDF for the same interatomic interactions. Inspection of Table 5 show that about $3 \mathrm{PC}$ molecules are placed around the $\mathrm{H}_{\mathrm{A}}$ and $\mathrm{C}_{\mathrm{R}}$ atoms, about 2 are placed around the $\mathrm{H}_{\mathrm{B}}$ and $\mathrm{C}_{\mathrm{W}}$ atoms of imidazole ring. In total $\mathrm{O} 1-\mathrm{H}_{\mathrm{A}}$ and $\mathrm{O} 1-\mathrm{H}_{\mathrm{B}}$ interatomic interactions show that there are 5 or 6 molecules of $\mathrm{PC}$ in the first solvation shell of $\mathrm{BMIM}^{+}$cation. Based on these data one of the possible instantaneous configurations of the first solvation shell presented in Fig. 7.

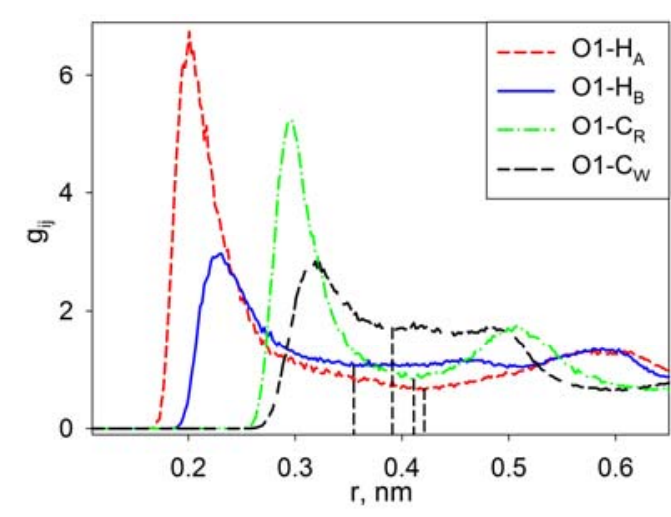

Figure 5. RDF of interatomic interactions between carbonyl oxygen atom of $\mathrm{PC}$ and atoms of imidazole ring of $\mathrm{BMIM}^{+}$cation.

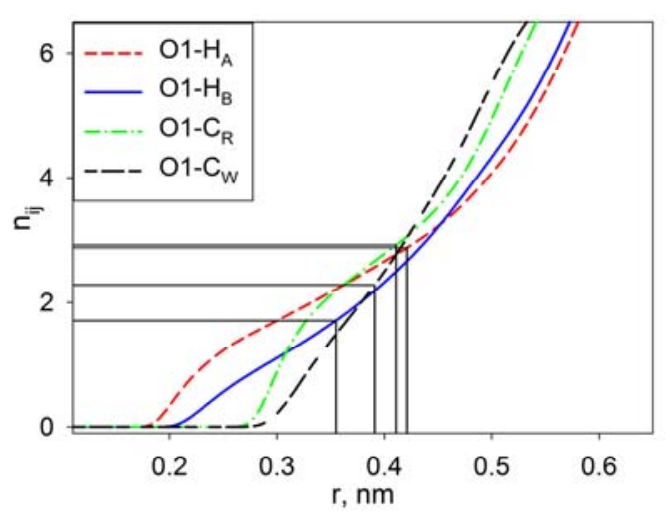

Figure 6. RCN for interatomic interactions between carbonyl oxygen atom of $\mathrm{PC}$ and atoms of imidazole ring of $\mathrm{BMIM}^{+}$cation.

Table 5. The structural parameters of cation-solvent site-site interactions within the first solvation shell of $\mathrm{BMIM}^{+}$in PC

\begin{tabular}{cccc}
\hline Pair of atoms & $r_{\max , 1}, \mathrm{~nm}$ & $r_{\min , 1}, \mathrm{~nm}$ & Coordination number \\
\hline O- $\mathrm{H}_{\mathrm{A}}$ & 0.201 & 0.420 & 2.84 \\
$\mathrm{O}-\mathrm{C}_{\mathrm{R}}$ & 0.295 & 0.410 & 2.92 \\
$\mathrm{O}-\mathrm{H}_{\mathrm{B}}$ & 0.229 & 0.355 & 1.70 \\
$\mathrm{O}-\mathrm{C}_{\mathrm{W}}$ & 0.319 & 0.390 & 2.25 \\
\hline
\end{tabular}

It should be noted that the most probable distance of the carbonyl oxygen atom to the center of the imidazole ring was $0.329 \mathrm{~nm}$ that is less than intrinsic radius of the $\mathrm{BMIM}^{+}$cation $(0.364 \mathrm{~nm})$ obtained from quantum-chemical calculations. This fact indicates the penetration of PC into the internal space of the cation. Such organization of solvation shell leads to the negative contribution into the 
solvated volume which is in accordance with the mentioned above results of the densimetry experiment.

\section{Conclusions}

Density of $\mathrm{BMIMBF}_{4}, \mathrm{BMIMPF}_{6}, \mathrm{BMIMBr}$ in $\mathrm{PC}$ was investigated with high accuracy at 298.15, $318.15,338.15$ and $358.15 \mathrm{~K}$. From the obtained experimental data using Masson equation the limiting partial molar volumes of RTILs in PC were obtained and divided into ionic contributions. The limiting partial molar volumes of $\mathrm{BMIM}^{+}$cation obtained from three RTILs with different anions was found to have the same values $115 \mathrm{~cm}^{3} / \mathrm{mol}$.

A quantum-chemical calculation (QQC) was carried out in order to optimize the geometry and obtain the intrinsic radius of the $\mathrm{BMIM}^{+}$cation. The radius obtained from QQC was $0.364 \mathrm{~nm}$ and the intrinsic volume of cation was $122 \mathrm{~cm}^{3} / \mathrm{mol}$. Comparison of the cation volume from density experiment and QQC indicates that solvation of cation has a negative contribution to the volume of ion in PC.

The microstructure of the first solvation shell of $\mathrm{BMIM}^{+}$cation in $\mathrm{PC}$ was investigated by molecular dynamics simulation of infinitely diluted solution of $1 \mathrm{BMIM}^{+}$in $215 \mathrm{PC}$ in the $N V T$ ensemble at $298.15 \mathrm{~K}$. It was shown that the most probable coordination center of PC molecule with respect to the $\mathrm{BMIM}^{+}$cation is carbonyl oxygen. It interacts mostly with hydrogen atoms of imidazole ring of the $\mathrm{BMIM}^{+}$cation. This results in formation of the first solvation shell consisting in 5-6 PC molecules which tend to penetrate the inner space of the cation.

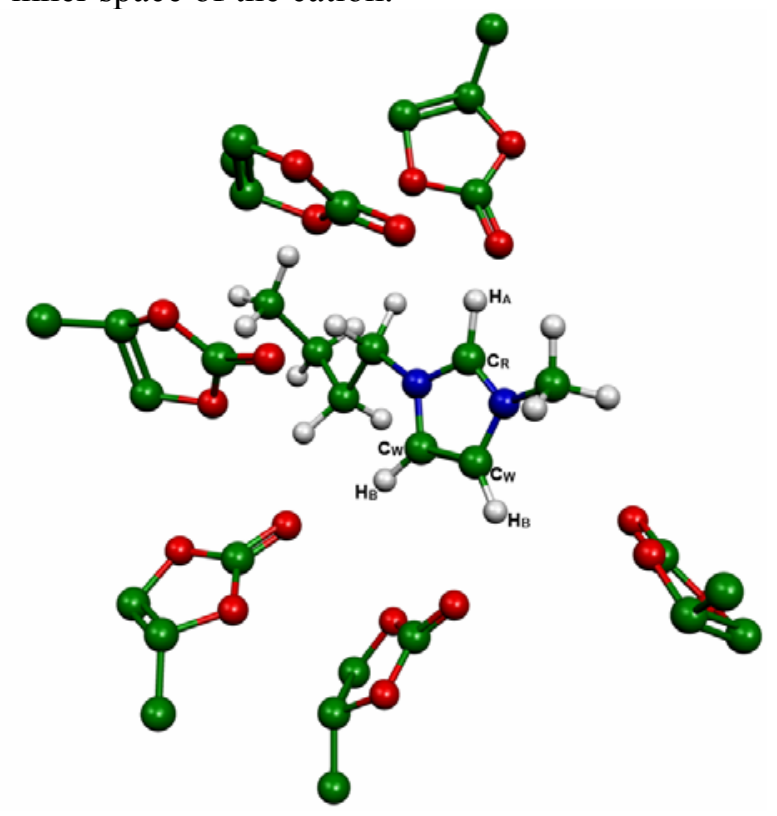

Figure 7. Instantaneous configuration of the first solvation shell of $\mathrm{BMIM}^{+}$cation in $\mathrm{PC}$.

\section{Acknowledgements}

Authors acknowledge the Grant No.0118U002025 of Ministry of Education and Science of Ukraine for the financial support.

\section{References}

1. Ue M., Takeda M., Toriumi A., Kominato A., Hagiwara R., Ito Y. Application of lowviscosity ionic liquid to the electrolyte of double-layer capacitors. J. Electrochem. Soc. 2003, 150 (4), A499-A502.

2. Plechkova N. V., Seddon K. R. Applications of ionic liquids in the chemical industry. Chem. Soc. Rev. 2008, 37 (1), 123-150.

3. Husson E., Hadad C., Huet G., Laclef S., Lesur D., Lambertyn V., Jamali A., Gottis S., Sarazin C., Nguyen Van Nhien A. The effect of room temperature ionic liquids on the 
selective biocatalytic hydrolysis of chitin via sequential or simultaneous strategies. Green Chem. 2017, 19 (17), 4122-4131.

4. Gong X., West B., Taylor A., Li L. Study on nanometer-thick room-temperature ionic liquids (RTILs) for application as the media lubricant in heat-assisted magnetic recording (HAMR). Ind. Eng. Chem. Res. 2016, 55 (22), 6391-6397.

5. Shi C., Jia Y., Zhang C., Liu H., Jing Y. Extraction of lithium from salt lake brine using room temperature ionic liquid in tributyl phosphate. Fusion Eng. Des. 2015, 90, 1-6.

6. R. MacFarlane D., Tachikawa N., Forsyth M., Pringle J., Howlett P., Elliott G., Davis J., Watanabe M., Simon P., Angell C. Energy applications of ionic liquids. 2014; Vol. 7, p 232.

7. Chagnes A., Diaw M., Carré B., Willmann P., Lemordant D. Imidazolium-organic solvent mixtures as electrolytes for lithium batteries. J. Power. Sources. 2005, 145 (1), 82-88.

8. Ruiz V., Huynh T., Sivakkumar S. R., Pandolfo A. G. Ionic liquid-solvent mixtures as supercapacitor electrolytes for extreme temperature operation. RSC Adv. 2012, 2 (13), 5591-5598.

9. Wang P., Zakeeruddin S. M., Moser J.-E., Grätzel M. A new ionic liquid electrolyte enhances the conversion efficiency of dye-sensitized solar cells. J. Phys. Chem. B 2003, 107 (48), 13280-13285.

10. Hardwick L. J., Buqa H., Holzapfel M., Scheifele W., Krumeich F., Novák P. Behaviour of highly crystalline graphitic materials in lithium-ion cells with propylene carbonate containing electrolytes: An in situ Raman and SEM study. Electrochim. Acta 2007, 52 (15), 4884-4891.

11. Allen J. L., Borodin O., Seo D. M., Henderson W. A. Combined quantum chemical/Raman spectroscopic analyses of $\mathrm{Li}^{+}$cation solvation: Cyclic carbonate solvents - ethylene carbonate and propylene carbonate. J. Power Sources 2014, 267, 821-830.

12. Krakowiak J. Apparent molar volumes and compressibilities of tetrabutyl-ammonium bromide in organic solvents. J. Chem. Thermodyn. 2011, 43 (6), 882-894.

13. Marcus Y. The standard partial molar volumes of ions in solution. Part 3. Volumes in solvent mixtures where preferential solvation takes place. J. Solution Chem. 2005, 34 (3), 317-331.

14. Roy M. N., Chanda R., Chakraborti P., Das A. Conductivity is a contrivance to explore ionpair and triple-ion structure of ethanoates in tetrahydrofuran, dimethyl sulfoxide and their binaries. Fluid Phase Equilibr. 2012, 322-323, 159-166.

15. Zhao Y., Wang J., Lu H., Lin R. Standard partial molar volumes of some electrolytes in ethylene carbonate based mixtures. J. Chem. Thermodyn. 2004, 36 (1), 1-6.

16. Giesecke M., Meriguet G., Hallberg F., Fang Y., Stilbs P., Furo I. Ion association in aqueous and non-aqueous solutions probed by diffusion and electrophoretic NMR. Phys. Chem. Chem. Phys. 2015, 17 (5), 3402-3408.

17. Molinou I. E., Tsierkezos N. G. Study of the interactions of sodium thiocyanate, potassium thiocyanate and ammonium thiocyanate in water+N,N-dimethylformamide mixtures by Raman spectroscopy. Spectrochim. Acta A 2008, 71 (3), 954-958.

18. Moon H., Mandai T., Tatara R., Ueno K., Yamazaki A., Yoshida K., Seki S., Dokko K., Watanabe M. Solvent activity in electrolyte solutions controls electrochemical reactions in Li-ion and Li-sulfur batteries. J. Phys. Chem. C 2015, 119 (8), 3957-3970.

19. Pires J., Timperman L., Jacquemin J., Balducci A., Anouti M. Density, conductivity, viscosity, and excess properties of (pyrrolidinium nitrate-based protic ionic liquid + propylene carbonate) binary mixture. 2013; Vol. 59, p 10-19.

20. Vraneš M., Zec N., Tot A., Papović S., Dožić S., Gadžurić S. Density, electrical conductivity, viscosity and excess properties of 1-butyl-3-methylimidazolium bis(trifluoromethylsulfonyl)imide+propylene carbonate binary mixtures. J. Chem. Thermodyn. 2014, 68, 98-108.

21. Zarrougui R., Dhahbi M., Lemordant D. Effect of temperature and composition on the transport and thermodynamic properties of binary mixtures of ionic liquid N-butyl-Nmethylpyrrolidinium bis(trifluoromethanesulfonyl)imide and propylene carbonate. J. Solution. Chem. 2010, 39 (7), 921-942.

22. Zhang Q., Li Q., Liu D., Zhang X., Lang X. Density, dynamic viscosity, electrical conductivity, electrochemical potential window, and excess properties of ionic liquid N-butyl- 
pyridinium dicyanamide and binary system with propylene carbonate. J. Mol. Liq. 2018, 249, 1097-1106.

23. Masson D. O. XXVIII. Solute molecular volumes in relation to solvation and ionization. The London, Edinburgh, and Dublin Philos. Mag. and J. Sci. 1929, 8 (49), 218-235.

24. Viana C. A. N., Dilo M., Segurado M. A. P. Temperature effects on conductivities and association constants of Lithium and tetra-ethylammonium salts in six aprotic solvents of medium to high permittivities from $-30{ }^{\circ} \mathrm{C}$ to $+10{ }^{\circ} \mathrm{C}$. Port. Electrochim. Acta 2004, 22, 179-192.

25. Moumouzias G., Ritzoulis G. Relative permittivities and refractive indices of propylene carbonate + toluene mixtures from 283.15 K to 313.15 K. J. Chem. Eng. Data 1997, 42 (4), 710-713.

26. Muhuri P. K., Hazra D. K. Electrical conductances for some tetraalkylammonium bromides, lithium tetrafluoroborate and tetrabutylammonium tetrabutylborate in propylene carbonate at $25^{\circ}$ C. J. Chem. Soc. Faraday T. 1991, 87 (21), 3511-3513.

27. Jansen M. L., Yeager H. L. Conductance study of 1-1 electrolytes in propylene carbonate. J. Phys. Chem. B 1973, 77 (26), 3089-3092.

28. Casteel J. F., Angel J. R., McNeeley H. B., Sears P. G. Conductance-viscosity studies on some moderately concentrated nonaqueous electrolyte solutions from minus 50 degree to 125 degree $\mathrm{C}$ - 2. Solutions of $\mathrm{Pr}_{4} \mathrm{NBr}, \mathrm{Bu}_{4} \mathrm{NBr}$, and $\mathrm{Bu}_{4} \mathrm{NI}$ in propylene carbonate. J. Electrochem. Soc. 1975, 122 (3), 319-324.

29. McDonagh P. M., Reardon J. F. Ionic association and mobility. III. Ionophores in propylene carbonate at $25^{\circ}$ C. J. Solution Chem. 1996, 25 (6), 607-614.

30. Salomon M., Plichta E. Conductivities and ion association of 1:1 electrolytes in mixed aprotic solvents. Electrochim. Acta 1983, 28 (11), 1681-1686.

31. Brouillette D., Perron G., Desnoyers J. E. Apparent molar volume, heat capacity, and conductance of lithium bis(trifluoromethylsulfone)imide in glymes and other aprotic solvents. J. Solution Chem. 1998, 27 (2), 151-182.

32. Ue M. Conductivities and ion association of quaternary ammonium tetrafluoroborates in propylene carbonate. Electrochim. Acta 1994, 39 (13), 2083-2087.

33. Barthel J., Utz M., Groß K., Gores H. J. Temperature and composition dependence of viscosity I. Propylene carbonate-dimethoxyethane mixtures and thermodynamics of fluid flow. J. Solution Chem. 1995, 24 (11), 1109-1123.

34. $\mathrm{Xu} \mathrm{K}$. Nonaqueous liquid electrolytes for lithium-based rechargeable batteries. Chem. Rev. 2004, 104 (10), 4303-4418.

35. D'Aprano A., Salomon M., Iammarino M. Conductance of alkali metal perchlorates in propylene carbonate at $25^{\circ} \mathrm{C}$. J. Electroanal. Chem. 1996, 403 (1), 245-249.

36. Marcus Y., Hefter G. Standard partial molar volumes of electrolytes and ions in nonaqueous solvents. Chem. Rev. 2004, 104 (7), 3405-3452.

37. Frisch M. J., Trucks G. W., Schlegel H. B., Scuseria G. E., Robb M. A., Cheeseman J. R., Scalmani G., Barone V., Mennucci B., Petersson G. A., Nakatsuji H., Caricato M., Li X., Hratchian H. P., Izmaylov A. F., Bloino J., Zheng G., Sonnenberg J. L., Hada M., Ehara M., Toyota K., Fukuda R., Hasegawa J., Ishida M., Nakajima T., Honda Y., Kitao O., Nakai H., Vreven T., Montgomery J. A., Peralta J. E., Ogliaro F., Bearpark M., Heyd J. J., Brothers E., Kudin K. N., Staroverov V. N., Kobayashi R., Normand J., Raghavachari K., Rendell A., Burant J. C., Iyengar S. S., Tomasi J., Cossi M., Rega N., Millam J. M., Klene M., Knox J. E., Cross J. B., Bakken V., Adamo C., Jaramillo J., Gomperts R., Stratmann R. E., Yazyev O., Austin A. J., Cammi R., Pomelli C., Ochterski J. W., Martin R. L., Morokuma K., Zakrzewski V. G., Voth G. A., Salvador P., Dannenberg J. J., Dapprich S., Daniels A. D., Farkas, Foresman J. B., Ortiz J. V., Cioslowski J., Fox D. J., Gaussian 09, Revision B.01. Wallingford CT, 2009.

38. Kalugin O. N., Volobuev M. N., Kolesnik Y. V. MDNAES: the program set for computer modelling of ion-molecular systems by using molecular dynamics method. Kharkov University Bulletin 1999, 454, 58-79.

39. Payne R., Theodorou I. E. Dielectric properties and relaxation in ethylene carbonate and propylene carbonate. J. Phys. Chem. 1972, 76 (20), 2892-2900. 
40. Arbad B. R., Lande M. K., Wankhede N. N., Wankhede D. S. Viscosities, ultrasonic velocities at $(288.15$ and 298.15$) \mathrm{K}$, and refractive indices at (298.15) $\mathrm{K}$ of binary mixtures of 2,4,6-trimethyl-1,3,5-trioxane with dimethyl carbonate, diethyl carbonate, and propylene carbonate. J. Chem. Eng. Data 2006, 51 (1), 68-72.

41. Postupna O. O., Kolesnik Y. V., Kalugin O. N., Prezhdo O. V. Microscopic structure and dynamics of $\mathrm{LiBF}_{4}$ solutions in cyclic and linear carbonates. J. Phys. Chem. B 2011, 115 (49), 14563-14571.

42. Mondal A., Balasubramanian S. Quantitative prediction of physical properties of imidazolium based room temperature ionic liquids through determination of condensed phase site charges: a refined force field. J. Phys. Chem. B 2014, 118 (12), 3409-3422.

43. Koverga V., Kalugin O., Alexandre Miannay F., Smortsova Y., Goloviznina K., Marekha B., Jedlovszky P., Abdenacer I. The local structure in $\mathrm{BmimPF}_{6} /$ acetonitrile mixture: The charge distribution effect. Phys. Chem. Chem. Phys. 2018, 20, 21890-21902.

Поступила до редакиії 13 листопада 2018 р.

А.В. Рябчунова*, В.М. Карабцова*, О.Н. Калугин*. Плотность и сольватационные эффекты ионных жидкостей на основе имидазолия в пропиленкарбонате.

* Харьковский национальный университет имени В.Н. Каразина, химический факультет, кафедра неорганической химии, площадь Свободы, 4, Харьков, 61022, Украина

Представлены результаты денсиметрического исследования растворов тетрафторобората $\left(\mathrm{BMIMBF}_{4}\right)$, гексафрторофросфата $\left(\mathrm{BMIMPF}_{6}\right)$ и бромида $(\mathrm{BMIMBr})$ 1-бутил-3-метилимидазолия в пропиленкарбонате (PC) при 298.15, 318.15, 338.15 и 358.15 К. Полученные данные рассмотрены с точки зрения кажущихся парциальных мольных объемов и вклада сольватации. Измерения плотности выполнены с использованием денсиметра Mettler Toledo DM 50 с точностью $\pm 3 \cdot 10^{-5} \mathrm{r}_{\mathrm{cm}}{ }^{3}$.

Предельные парциальные мольные объемы исследованных ионных жидкостей в пропиленкарбонате были получены из экспериментальных данных по плотности с использованием уравнение Мэссона и разделены на ионные вклады. Предельные парциальные мольные объемы $\mathrm{BMIMBF}_{4}, \mathrm{BMIMPF}_{6}$ и $\mathrm{BMIMBr}$ в PC незначительно увеличиваются с ростом температуры. Предельный парциальный мольный объем катиона BMIM ${ }^{+}$, полученный из трех ионных жидкостей с разными анионами, имеет одинаковую величину $115 \mathrm{~cm}^{3} /$ моль при $298.15 \mathrm{~K}$.

Собственный радиус катиона $\mathrm{BMIM}^{+}$, рассчитанный квантово-химически на уровне M062X/6-311++G(d,p), оказался больше чем полученный из эксперимента по плотности и указывает на то, что сольватация вносит отрицательный вклад в кажущийся парциальный мольный объем иона в пропиленкарбонате.

Для исследования микроскопической структуры сольватной оболочки $\mathrm{BMIM}^{+}$в PC выполнено молекулярно-динамическое моделирование бесконечно разбавленного раствора в NVT ансамбле при $298.15 \mathrm{~K}$. Результаты моделирования указывают на то, что первая сольватная оболочка катиона состоит из 5-6 молекул пропиленкарбоната, проникающих во внутреннее пространство катиона, что согласуется с результатами денсиметрического эксперимента. Из анализа функций радиального распределения и текущих координационных чисел катион-молекула растворителя установлено, что наиболее вероятным координационным центром молекулы РС является кислород карбонильной группы.

Ключевые слова: денсиметрия, плотность, кажущийся парциальный молярный объем, сольватация, 1-бутил-3-метилимидазолий, тетрафтороборат, гексафторофосфрат, бромид, пропиленкарбонат, молекулярно-динамическое моделирование.

А.В. Рябчунова*, В.М. Карабцова*, О.Н. Калугін*. Густина і сольватаційні ефректи іонних рідин на основі імідазолія в пропілен карбонаті.

* Харківський національний університет імені В.Н. Каразіна, хімічний фракультет, кафедра неорганічної хімії, майдан Свободи, 4, Харків, 61022, Україна

Представлені результати денсиметричного дослідження розчинів тетрафтороборату (BMIMBF 4 ), гексафтторофросфату $\left(\mathrm{BMIMPF}_{6}\right)$ і броміду $(\mathrm{BMIMBr})$ 1-бутил-3-метилімідазолія в пропілен карбонаті (PC) при $298.15,318.15,338.15$ та 358.15 К. Отримані дані розглянуті з точки зору уявних парціальних мольних об'ємів і вкладу сольватації. Вимірювання густини виконані з використанням денсиметра Mettler Toledo DM 50 з точністю $\pm 3 \cdot 10^{-5} \mathrm{r} / \mathrm{cm}^{3}$.

Граничні парціальні молярні об'єми досліджених іонних рідин в РС були отримані з експериментальних даних по густині з використанням рівняння Мессона і розділені на іонні складові. Граничні парціальні молярні об'єми $\mathrm{BMIMBF}_{4}, \mathrm{BMIMPF}_{6}$ и $\mathrm{BMIMBr}$ в PC незначно збільшуються з ростом температури. Граничний парціальний молярний об'єм катіона $\mathrm{BMIM}^{+}$, отриманий з трьох іонних рідин з різними аніонами, має одна- 
кову величину $115 \mathrm{~cm}^{3} /$ моль при $298.15 \mathrm{~K}$.

Власний радіус катіона BMIM $^{+}$розрахований квантово-хімічно на рівні M062X/6-311++G(d,p) виявився більше ніж отриманий з експерименту по густині і вказує на те, що сольватація вносить негативний вклад до уявного парціального молярного об'єму іона в пропілен карбонаті.

Для дослідження мікроскопічної структури сольватної оболонки ВMІМ $^{+}$в РС виконано молекулярнодинамічне моделювання безмежно розведеного розчину в NVT ансамблі при 298.15 K. Результати моделювання вказують на те, що перша сольватна оболонка катіона складається з 5-6 молекул пропілен карбонату, що проникають у внутрішній простір катіона, що узгоджується з результатами денсиметричного експерименту. 3 аналізу функцій радіального розподілу та поточних координаційних чисел катіон-молекула розчинника встановлено що найбільш ймовірним координаційним центром молекули РС є Оксиген карбонільної групи.

Ключові слова: денсиметр, густина, парціальний молярний об'єм, сольватація, 1-бутил-3метилімідазолій, тетрафтороборат, гексафторофосфат, бромід, пропілен карбонат, молекулярнодинамічне моделювання.

Kharkov University Bulletin. Chemical Series. Issue 31 (54), 2018 